\title{
Innovative capital resources - South Canterbury
}

\author{
B.J.M. LOVE \\ 24 The Terrace, PO Box 457, Timaru 7940, New Zealand \\ BLove@kpmg.co.nz
}

South Canterbury has a history of innovative capital investment in agriculture, as a rural region of New Zealand. Henry Sewell, an early Canterbury politician, said in 1956 that "Timaru is a miserable apology for a shipping place without wood or water. Nothing will ever spring up there but a public-house, a store and a woolshed". Luckily, with innovative use of capital resources that predication has been proven wrong.

The first major capital investment was the Timaru Port, officially established during the 1870 s. The port has now grown to be the major port of trade in the South Island, and with the vision of recent governance, has seen the development of a successful joint venture with the Port of Tauranga. The Timaru Port represents the region well, not because of its success, but by succeeding during difficult times and having a story to tell about itself.

The port is the gateway to the regions customers, however, recent capital investment has occurred more at the headwaters of the region. In the last century the quest for electricity drove government investment into South Canterbury and that saw the hydro-power generation schemes built in late 1950s and 1960s. A number of dams were created channelling power generation from the snow melt off the Southern Alps, to flow down the Waitaki River.

While electricity power generation was the main reason for the development, recreational facilities and irrigation for farm land resulted.

During the 1970s irrigation was established by the government in the Morven, Glenavy and Ikawai areas. The scheme utilised water from the Waitaki River that had increased flows because of the influence of dams above. This scheme has since increased its area, remaining owned $100 \%$ by farmer shareholders and is one of the most sustainable irrigation schemes in New Zealand today.

From 1996 to 2016, capital investment in South Canterbury has grown at a fast pace. That growth took many routes, including private investment by individuals, banking support and cooperate investment plus vision from people like the late Sir Peter Elworthy, the late Allan Hubbard, Tom Henderson, Robin Murphy and Gary Rooney, to name a few. In recent years the region has seen:

- Dairying expansion, and with Fonterra's formation in 2001 a major increase in on-farm development starting with the conversion of dry stock and cropping farms to dairying. In 1998 there were 112 herds with about 47000 cows; by 2015 there were 303 herds with 243000 cows. Based on the average capital employed in this conversion and development it is estimated to be an investment of around $\$ 1.3$ billion over 17 years.

- On the wave of the dairy boom came massive local investment in milk processing infrastructure at Clandeboye and then the building of the Studholme processing plant, and more recently the independent processor, Oceania, at Glenavy.

- The "land change" bug was fuelled by successful expansion of district irrigation schemes. The Ophua Dam development in the mid-1990s (opening in 1999), saw a way forward for future farmer-owned scheme development without direct government capital support. From this, further capital development occurred in irrigation with the Kakahu and the Sutherland scheme, extension of the Morven Glenavy Ikawai scheme, the Rangitata South irrigation scheme, and most recently, the Waiho Downs irrigation scheme.

- Irrigation brought changes to on-farm systems, and certainly, the development of centre pivot irrigation has also seen heavy investment into onfarm infrastructure. Alternative crops started to be produced including potatoes, carrots, onions, maize, black currents, Honey Crisp apples and specialised vegetable seed crops.

- Irrigation allowed dry land farmers to have alternative customers that could fatten stock within the local area. Dry land cropping areas expanded to feed the growing dairy community. This lead to expansion of capital improvements on dry land operations in the area.

- Water availability facilitated intensification of farming either into fattening operations or supplying feed to the dairy industry by way of dairy grazing or cropping. Farm values have risen progressively, similar to other parts of New Zealand.

- Other capital investment in the area has seen successful businesses like Alliance, Silver Fern Farms, McCain's, the Farmers Flour Mill, Barkers Fruit Processors, Talbot Cheese and Southern Packers onion packing house, to name a few, that have established bases in South Canterbury. These provide processing options for farmers and employment for the urban community. 
So welcome to South Canterbury and Timaru city, it cannot be said that we are an apology for a shipping place, we are a self-grown and vibrant region. The region has to continue sustainable investment to ensure that we continue to punch above our weight nationally. This will be an ongoing challenge. 